\title{
特集「ポスト東日本大震災の防災・減災まちづくり」にあたって Disaster Prevention and Mitigation in the Post East Japan Great Earthquake Era
}

\author{
中井 検裕（東京工業大学大学院社会理工学研究科教授 出版編集委員）
}

Norihiro NAKAI

東日本大震災から 5 年を迎えようとしている。震災は被災地に甚大な人的・物的被害をもたら したのみならず，直接の被災地以外の地域，ひいてはわが国全国の防災・減災の考え方に大きな 影響を与えた。近い将来発生が予想されている首都圈直下や東海・東南海・南海地震の被害想定 は根底から見直され，それに向けた対策も，レジリエンシーをキーワードに，インフラ整備から 避難・事業継続など，ハードな施設整備からソフトな体制・システムづくりに至るまで多岐にわ たって様々な取り組みがなされつつある。加えて, 想定される災害の種類も地震だけでなく, 気 候変動を念頭に台風, 集中豪雨, ゲリラ豪雨などの水害や, 2014年の御訔山噴火, 2015年の口永 良部島を契機に，火山災害などにも広がりつつある。

日本列島に生活し，経済活動を営んでいる限り，こうした自然災害から逃れることはできない。 東日本大震災から 5 年が経過し，私たちは大震災から何を学び，次の大災害にどのように対応し ようとしているのか。本特集は，わが国の防災・減災まちづくりは東日本大震災を契機にどのよ うに変わってきているのか, 現時点での到達点を整理すると同時に, より安全な都市づくり, 国 土づくりの観点からの評価を試みたものである。

特集は, 10の論説から構成されている。

最初の三井論説は，阪神・淡路大震災後の様々な取り組みが，東日本大震災でどのように活か されたのかを総括的に検証したものである。次の生田論説は, 災害に対応するための法制度と復 興の法制度について，東日本大震災以降の動きを総括し，今後の課題を論じたものである。第 3 の清水論説は, 東日本大震災が不動産市場に与えた影響を, 国内投資と海外からの投資の両面か ら評価を試みたものである。第 4 の市古論説は，災害の発生前から災害を想定してまちづくりを 進める事前復興まちづくりについて，長期，中期，短期の視点から到達点を整理し，評価したも のである。第 5 の姥浦論説は, 災害リスクに応じた土地利用コントロールについて, その有効性 と運用の困難さを明確にした上で, 今後のあり方を論じたものである。第 6 の齊藤論説は, 災害 時にマンションがどのように機能し, 地域に寄与しうるかを, 東日本大震災時の経験から, 期待 と課題について論じたものである。第 7 の中嶋論説は, 災害時の企業の事業継続について，わが 国屈指の大企業本社が集中する丸の内地区を例に，特に地区としてのBCPへの取り組みを紹介し， 業務地区での防災まちづくりの新たな方向を示したものである。第 8 の田中論説は, 首都圈直下 地震では最悪の場合, 500 万人上発生すると想定されている帰宅困難者について，その対策は どのようになっているか，現状を紹介するとともに，限界と課題を論じたものである。第 9 の中 城論説は，人的な被害ではないものの資産価值に大きな影響を与える液状化被害をテーマに，被 害地区である浦安を事例として, 液状化が住宅地の価值に与えた影響とその復興過程, さらには 今後の対策を論じたものである。最後の栗山論説は, 災害からの復旧に有効な手段と考えられる 災害保険について，地震保険を対象に有効性と課題を論じたものである。

いずれの論説も，東日本大震災によって前進した部分がある一方で，少なからぬ課題が残され ていることも指摘されている。2011年 3 月11日の午後 2 時46分に自分がどこにいて，何をしてい たかを覚えている人は多いと思うが，個人ではなく社会としての震災の記憶は，直接の被䇚地を 除いては， 5 年が経過し，風化してきていることは事実であろう。今回の特集によって，私たち が災害大国に暮らしていることを再認識し，東日本大震災で亡くなった多くの犠牲者のためにも， より安全で安心な国土づくりに取り組まねばならないことを，もう一度思い返してもらえること を願う。 